\title{
IPABA checklist for Heritage in Spanish: How to Assess Visibility and Accessibility on the Web
}

\begin{abstract}
The authors propose a new index called IPABA - composed by the evaluation criteria: Identification, Presence, Audience, Browsability), Accesibility- for determining the potential visibility of UNESCO World Heritage Sites in Spain and Mexico on the basis of their official websites. This index is based on a checklist which includes new categories and items that influence the visibility of these websites. The sample is exhaustive, comprising the 114 Mexican and Spanish websites that are the official, government-sanctioned online representations of the World Heritage Sites in question.

The results reveal changes in social behavior with regard to communication. The majority of the websites assessed had an overall score that was very acceptable with more than 650 points of a maximum of 1000, although differences were observed between countries in terms of presence on social networks.
\end{abstract}

Keywords: Webpage assessment; Web evaluation methodologies; Web visibility; Performance measurements; World Heritage Sites; World Heritage List

\section{Introduction}

The ease with which websites can be created and disseminated via the World Wide Web has led to "information overload." Websites strive to make themselves visible to search engines and increase their popularity by attracting online traffic, as Wang and $\mathrm{Xu}$ affirm (Wang and $\mathrm{Xu}, 292$ 3).

In recent years, studies have been made of website visibility in general (Gori and Witten, "Bubble"; Lim and Park, "Congressional Members"; Kouchay, "Evaluation of World Ranking"), their relation to professional reputation (AbuSerriah, et al., "Assessment"), and how this improves commercial and business marketing (Wang and Xu, "Who Needs"; Miranda, et al., "Hotel Websites"; Wang and Vaughan, "Firm Web Visibility"; Drèze and Zufryden, "Online Visibility"). Other studies focus on evaluating the quality of these websites to achieve increased recognition across social networks in the university sphere (Aaltojärvi et al., "Scientific Productivity"; Lee and Woo Park, "Exploring the Web"). However, it has also been shown that quality does not always equal popularity, and vice versa (Caro, et al., "Web Visibility"; Samadbeik, et al., "Health Information"). Can these findings be extrapolated to any other area? How about to World Heritage sites?

In the context of cultural heritage, there is no other condition beyond visibility that can bestow more authority and trustworthiness upon a site. After the United Nations Educational, Scientific and Cultural Organization (UNESCO) declares something a World Heritage Site, the site then comes under the guardianship of an official body, whether governmental or, in a small number of cases, private. These official bodies, therefore, must work to achieve good positioning and visibility for the corresponding websites. As with any website, design and content must be 
planned carefully, but in this instance, given that the content is of international interest, the language used for searches can also be important.

\section{Objectives}

This study explores the following research questions: (a) Can a ranking be created for website visibility? (b) Which elements to facilitate website visibility are most commonly used by webmasters? First, we propose creating an index to reflect the elements that may be useful in increasing the visibility of websites and institutional domains.

Second, we establish a framework for measuring the visibility of the websites pertaining to the bodies responsible for disseminating information regarding World Heritage sites, using new criteria that reflect the recent panorama.

[We note that there are quantitative measures of website visibility. For example, one can count the number of times a site is visited and for how long. It is also possible to optimize positioning on the web by paying for it. These approaches to website visibility are not the focus of our research.]

\section{Literature Review}

\subsection{Authority vs. Trust}

Popularity is usually a consequence of the trust placed in a website in the form of traffic and direct links. From this premise, a number of studies have been made of some of the criteria employed by users when placing their trust in a website (Palau Sampio and Gómez Mompart, "Calidad y Credibilidad"; Singal and Kohli, "Trust"). These studies demonstrate that there is not always a correlation between trust and popularity.

A priori, the authority wielded by an institution can be a reason to trust it. This notion refers to the recognition that users bestow upon certain institutions or sources, and their consequent trust in the accuracy of the content provided by those institutions or sources. An assessment of the potential visibility of a website may therefore be determined by this factor. When this authority is confirmed through experience, it is transformed into reputation, which can then grow through word-of-mouth recommendation.

Our hypothesis is based on the fact that websites, as well as containing certain elements that are recommended for the purposes of SEO (Search Engine Optimization), also incorporate other elements into their design that allow for great technical and multilingual accessibility, and increase their online visibility and aid consultation (Weitzel, Quaresma, and Oliveira, "Evaluating Quality"). The point here is that perceived authority leads to increased use, and thus increased visibility.

\subsection{Website Assessment Criteria}

Since the turn of the 21st century, numerous website assessments have been carried out and classifications drawn up from a business perspective (Schmidt, et al., "Characteristics of Hotel Websites"). Our focus is on assessment based on certain characteristics. In other words, online 
presence and visibility go beyond merely creating a website and identifying it in search engines via its title or keywords in one or more languages (Ismail, et al., "Snapshot in Time"). Our aim is to break the boundaries of linguistics and accessibility by using W3C standards, because, as shown by Pemberton's "Kiss of the Spiderbot," accessible websites are used frequently by those with and without disabilities. Upon our accessing the website, it is necessary to determine whether information is provided to suit the user, and whether the website offers mechanisms for communicating with the user. This visibility also translates into a presence on, and ease of location and access to, the various social networks that currently exist on the Internet. There are different media formats we can use, including social networks such as Facebook and Twitter, collective sources of information such as Wikipedia, mentions in official directories or institutions, and so on (Gómez Cobos and Martínez-Osorio Ibarra, "Visibilidad en la Web"). These new factors must be studied in order for us to understand how they can influence reputation or popularity and how they can be incorporated as elements to help us assess visibility.

To summarize, website assessment has traditionally involved an evaluation of the quality of a website by analyzing its design, content, accessibility, and other criteria (Knight and Burn, "Developing a Framework"). However, this perspective has fallen out of favor in recent years, and positioning is now considered the factor that determines good visibility (Espadas, et al., "Web Site"). We include both perspectives in this study, albeit adapted in accordance with the evolution of Web 1.0 and Web 2.0.

\section{Materials and Methods}

Based the checklist we have drawn up, we have created an index to reflect the elements that may be useful in increasing the visibility of websites and institutional domains. The IPABA checklist is based on the evaluation criteria: Identification, Presence, Audience, Browsability and Accesibility. This method takes into account the authority and reputation of the institutions that promote and manage the World Heritage Sites in question and their respective websites; the ability to access these websites in different languages; the audiovisual content provided; and so on. The index allows us to quickly determine whether a website needs to be improved to increase its visibility.

Second, we have established a framework for measuring the visibility of the websites pertaining to the bodies responsible for providing information on World Heritage Sites. We have used the same framework to analyze their Web 2.0 presence. We have also assessed the communication facilities of each website with regard to accessibility (Kouchay, "Evaluation") and multilingualism, and identified their areas of weakness.

\subsection{Website Selection}

We identified the institutional domains of the bodies responsible for UNESCO World Heritage Sites in Spain and Mexico, countries that share an official language, Spanish, and are home to some of the highest concentrations of World Heritage Sites in the world (Spain occupies second place on the list and Mexico sixth). Moreover, they have comparable total production of goods and services, as shown by their respective GDP figures. However, there are also significant 
differences between them, in terms of geography, population, economics, and their management of cultural tourism and heritage. (Note: this study was begun in February 2016, when the number of sites granted World Heritage status by UNESCO stood at 33 for Mexico and 44 for Spain. Consequently, the Revillagigedo Archipelago and the Antequera Dolmens, which were declared World Heritage Sites in July 2016, do not form part of our sample.)

To find the official website URLs, we used search engines such as Google and Yahoo. Our search terms included the name used by UNESCO for each World Heritage Site and/or another variation of its name, if the variation was more recognizable. From the list of results, we identified websites that belong to the World Heritage Site in question. We excluded commercial websites and selected those that pertained to a particular public (preferably), private, or mixed body, to ensure the website's veracity.

Many World Heritage Sites did not have an "official” website as such, so we selected the URLs that provided the most information and the most reliable information; in other words, the websites that best represented the sites in question, whether they were created by a governmental body or some other type of institutional organization.

We also considered that a UNESCO World Heritage Site can encompass several cultural elements and/or a series of elements, and we therefore selected websites that referred to the World Heritage Site as a whole, or to one of the elements that was part of the site. For sites that comprise a series of elements, we selected the one that was most representative of the series in question. In other words, the URLs we selected pertain to all or part of the World Heritage Sites studied. This especially applies to "historic centers," "old towns," "monumental complexes," and "archaeological complexes," which refer to a set of architectural, urban, and archaeological legacies taken as a whole and which have comprised a "set" from their beginnings through to the present day (Calle Vaquero and Ruiz Lanuza, "Ciudades Patrimonio"). The website selection was expanded in order to represent these sets as accurately as possible, and they were broken down into a single URL for each official website pertaining to each of the elements that comprised the World Heritage Site in question.

Consequently, the list includes websites that provide the most information (e.g. in the case of Mérida ${ }^{1}$ ) and individual searches for the monuments that form part of historic city centers (e.g., Córdoba does not have a single website encompassing its entire historic center ${ }^{2}$ ). We have also included institutional domains of an agglomerative nature, such as the website for the city of Toledo (the Toledo-Turismo website ${ }^{3}$ ), as well as those that pertain to its most renowned monuments (e.g., the Alcázar ${ }^{4}$ [which now houses the Army Museum] and Toledo Cathedral ${ }^{5}$ ). Another example is the World Heritage Site comprising Granada's Alhambra, Generalife, and

\footnotetext{
${ }^{1}$ http://www.consorciomerida.org/

${ }^{2}$ Catedral de Córdoba: http://www.catedraldecordoba.es/

Alcázar de Córdoba: http://www.alcazardelosreyescristianos.cordoba.es

Puente romano de Córdoba:http://www.puenteromanocordoba.es/

La Judería:http://www.españaescultura.es/es/monumentos/cordoba/juderia.html

${ }^{3} \mathrm{http}: / / \mathrm{www}$. toledo-turismo.com/es/toledo-patrimonio-de-la-humanidad_114

${ }^{4}$ http://www.museo.ejercito.es

${ }^{5}$ http://www.catedralprimada.es/
} 
Albaicín, for which we included the website of the Board of Trustees (patronato) of the Alhambra and Generalife ${ }^{6}$ and the website of the Agencia Albaicín-Granada ${ }^{7}$, which is run by Granada City Council and is responsible for the management and protection of the Albaicín. We should remember, however, that there is a great deal of variation, and there are complexes incorporating several monuments that are well represented in just a single website.

In the case of Mexico, the most complicated websites to identify corresponded to historic city centers. They have the dual character of being living, functional cities, with their corresponding city councils, and a resultant selection of websites to choose from; and of being sites of cultural and tourist interest, with the resultant selection of websites created by private bodies (e.g., Moreliainvita.com), or institutional websites that agglomerate several locations within a single website and give each of them their own domain therein (e.g., Conaculta ${ }^{8}$, or ciudadespatrimonio. $\mathrm{mx}^{9}$ ).

For these reasons, in our sample it is possible for a particular World Heritage Site to be associated with more than one website. We have also chosen to include the corresponding websites specified on the UNESCO website, because although they may not offer the greatest amount of information, UNESCO is ultimately the official source of information in relation to World Heritage Sites. Additionally, a vital condition for inclusion on our list is that the websites had to identify their creators, and to have the backing of some sort of public, private, or mixed body that could support its veracity.

Having applied the criteria detailed above, we created a list of 71 websites for the 44 Spanish World Heritage Sites and 43 websites for the 33 Mexican World Heritage Sites. The majority of the sites related to cultural heritage, with a small number related to natural heritage (three in Spain and five in Mexico) or mixed heritage (two in Spain and one in Mexico). All of the World Heritage Sites had at least one website containing official information, and the list contains those that were considered the most authoritative or official, whether of a governmental or ecclesiastical nature. We conducted a search, via Google, of the full or partial name of the World Heritage Sites in question; and as this study is concerned with official bodies, we conducted the search in Spanish. Where we did not find an official website representing "historic centers," "old towns," "monumental complexes," or "archaeological complexes," we subdivided the World Heritage Site into sets of three or four monuments to determine the name used to represent the complexes in question. The difference between the number of websites and the number of World Heritage Sites is chiefly due to the use of separate websites to provide information on the various elements that comprise a single World Heritage Site (e.g., the Historic City Centre of Córdoba) or on a World Heritage Site that is comprised of several elements (e.g., the Alhambra, Generalife, and Albaicín, or the Historic Centre of Mexico City and

\footnotetext{
${ }^{6}$ www.alhambra-patronato.es

${ }^{7}$ www.albaicin-granada.com

${ }^{8} \mathrm{http} / / /$ www.conaculta.gob.mx/turismocultural/patrimonio_cultural/palenque/index.php\#ad-image-0 and http://www.conaculta.gob.mx/turismocultural/guias//guia1_2.php

${ }^{9} \mathrm{http}: / /$ ciudadespatrimonio.mx/tlacotalpan/landing, http://ciudadespatrimonio.mx/morelia/landing, http://ciudadespatrimonio.mx/oaxaca/landing, http://ciudadespatrimonio.mx/puebla/landing and http://ciudadespatrimonio.mx/zacatecas/landing
} 
Xochimilco ${ }^{10}$ ). On other occasions, we found more than one official body, as is the case with Mexico's National Commission for Protected Natural Areas (CONANP) and National Institute of Anthropology and History (INAH), which provide information on the Ancient Mayan City and Protected Tropical Forests of Calakmul, Campeche ${ }^{11}$.

\subsection{Preparing the Assessment Questionnaire}

We prepared a questionnaire to apply an empirical method that would generate an index of effectiveness for each institutional domain. The measurements that were made for our assessment form (IPABA) were based on the criteria of identification, presence and authority, audience (with a focus on content), and browsability and accessibility (technical and linguistic). Each website was assessed by means of an inspection.

To create our new assessment model, we drew upon and analyzed a number of existing models focusing on website analysis and assessment, such as those developed by GordonMurnane ("Evaluating Net”), Codina’s Evaluación de Calidad, Jiménez Piano ("Evaluación de Sedes Web"), and Ureña and Buendía ("Cómo Diseñar"). The criteria for the general analysis (Jiménez Piano and Ortiz-Repiso, Evaluación y Calidad) were based on considerations related to the searchability and findability of information, authority, content, administration, and design.

Our proposal is adapted in line with the idiosyncrasies of the set of institutional domains ${ }^{12}$ studied and their representation online. We have taken official—and therefore authorized - sources of information as our starting-point, and have therefore eliminated certain categories from this original protocol and added criteria highlighted by authors such as GordonMurnane, ("Evaluating"). Our aim is to offer a working method that is quick and easy to apply, has been updated in accordance with the current panorama (taking social networks into account), and is focused on visibility and accessibility. In this instance, the term is used in a general sense to refer to all types of URL: namely, websites, webpages and institutional domains.

Once we determined the items to be measured, we weighted them by using a prioritization matrix as Vilar Barrio, Gómez Fraile, and Tejero Monzón. The elements comprising the set in question were prioritized, creating a prioritization matrix with dual input. The assessment scale (Vilar Barrio, Gómez Fraile, and Tejero Monzón, "Siete Nuevas Herramientas") compares each pair of elements by assigning them a value of 1 if they are of equal importance, a value of 2 if one element is more important, and a value of 5 if one element is significantly more important than the other. As we are dealing with a dual-input matrix, the respective values were 2 (significantly more important), 1 (equally important) and 0.5 (less important). The weighting was calculated on an intrinsic basis, given that the relationships between all the elements that comprise the protocol are provided by their indicators and categories. Values were assigned on a staggered basis (see Figure 1).

\footnotetext{
${ }^{10}$ Centro Histórico Ciudad de México: http://www.autoridadcentrohistorico.df.gob.mx/ Delegación Xochimilco: http://www.xochimilco.df.gob.mx

${ }^{11} \mathrm{http}: / / c a l a k m u l . c o n a n p . g o b . m x /$ and http://www.inah.gob.mx/zonas/62-zona-arqueologica-de-calakmul

${ }^{12}$ In this instance, the term is used in a general sense to refer to all types of URL: namely, websites, and institutional domains.
} 


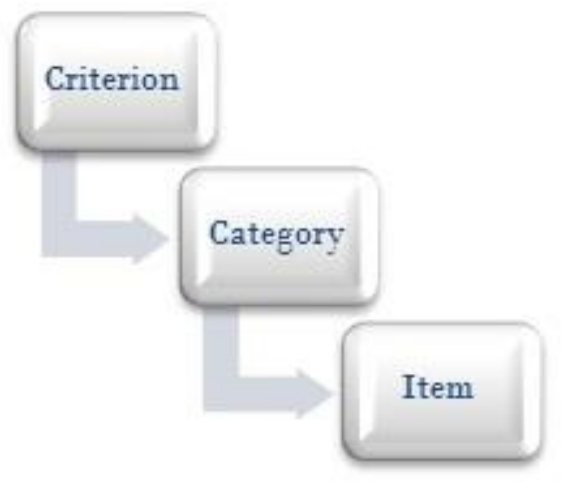

\section{Figure 1: The Process for Assigning Weight}

First, we determined the relationship between the various criteria (visibility and identification, presence and authority, audience, browsability and accessibility) as shown in Table 1, and then determined the relationship between the categories that comprise them. This stage of the study was carried out after the questionnaire was reviewed and accepted by eight experts, whose application of the assessment scale allowed us to calculate the different weights. These indicators, which pertain to the assessment criteria, were updated and adapted in accordance with the evolution of website design in general and particularly those representing institutions, with regard to format, clarity of presentation, and so on, as studied by researchers such as Ciolek ("Six Quests") and Wierenga ("Desire").

Our objective is to study not the websites' design, but rather their functionality, whether by analyzing the type of information provided, or identifying whether any type of template was used or design-related guidelines were followed in their creation. For the criteria related to administration, we selected institutional websites that are designed to provide information to the public; moreover, as these websites were created recently, it is not yet necessary to determine how up-to-date they are. Rather than determining the stability of the URL in question, we were more concerned with establishing its identity; consequently, we did not consider determining the URL's stability to be a priority. However, the possibility of the URL's being a webpage, website, or institutional domain is included in the "Authority and Administration" category.

In this study we have conducted an in-depth exploration of all of the factors related to the accessibility and interactivity of each website, and have identified potential channels of communication with the body in question (e.g., personalized attention in the form of online chat, email, etc.). As indicated by Yussuf Hassan Montero, the close relationship between accessibility and usability means that the former comprises an extremely important part of the latter. In a cause-effect relationship, usability is, in some ways, an effect of accessibility. 


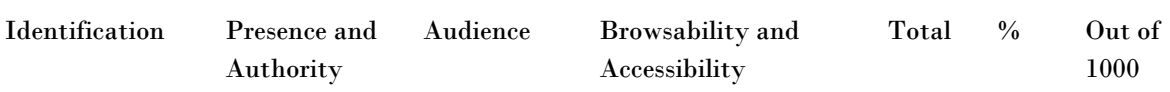

\begin{tabular}{|c|c|c|c|c|c|c|c|}
\hline Identification & & 0.5 & 0.5 & 1 & 2 & 0.15 & 148.15 \\
\hline $\begin{array}{l}\text { Presence and } \\
\text { Authority }\end{array}$ & 2 & & 1 & 1 & 4 & 0.30 & 296.30 \\
\hline Audience & 2 & 1 & & 0.5 & 3.5 & 0.26 & 259.26 \\
\hline $\begin{array}{l}\text { Browsability and } \\
\text { Accessibility }\end{array}$ & 1 & 1 & 2 & & 4 & 0.30 & 296.30 \\
\hline Total & 5 & 2.5 & 3.5 & 2.5 & 13.5 & 1.00 & 1000.00 \\
\hline
\end{tabular}

Table 1: Weighting of the Criteria in the IPABA Questionnaire

These criteria are broken down into categories, which are comprised of a series of indicators. Each category is assessed in relation to the other categories in the same criterion, and in accordance with its own particular weight. In our IPABA model, the "Audience" criterion includes only a single category, and the weight of this category therefore coincides with that of the item. In contrast, the criteria of "Presence" and "Browsability and Accessibility" reflect a greater amount of detail, and it is therefore necessary to add a third and final stage in which we calculate the weight of each indicator in the category in question.

\subsubsection{Criterion: Identification and Visibility}

This criterion refers to the qualities of being searchable (Gordon-Murnane) and findable (Morville) using an algorithm-based search engine. To facilitate these qualities, the website administrator must provide the relevant identifying elements so that the World Heritage Site in question can be found online.

Expressiveness of the URL: Search engines give greater visibility to web addresses that include terms which are descriptive and repeat the website's title (see Table 2). Our task was to assess whether the URL is sufficiently indicative of the institutional domain it pertains to.

Website title and keywords: We determined whether the keywords were sufficiently descriptive from a metadata perspective (Liu, Du and Tsai) and identified the language or languages they were found in. Beyond the creation and design of the website, our aim in this section is to determine whether the design includes a representative title for the website to facilitate its indexing in search engines, and thereby facilitate the finding of this particular source of information. 


\begin{tabular}{|c|c|c|c|c|}
\hline $\begin{array}{l}\text { A. IDENTIFICATION: } \\
\text { 148.15 } \\
\end{array}$ & $\begin{array}{l}\text { 1. Expressiveness of } \\
\text { the URL }\end{array}$ & $\begin{array}{l}\text { 2. Website title and } \\
\text { keywords }\end{array}$ & Total & Weight \\
\hline 1. Expressiveness of the URL & & 0.5 & 0.5 & 29.63 \\
\hline 2. Website title and keywords & 2 & & 2 & 118.52 \\
\hline Total & 2 & 2 & 2.5 & 148.15 \\
\hline
\end{tabular}

Table 2: Weighting of the Categories in the "Identification" Criterion

\subsubsection{Criterion: Presence and Authority}

Having a well-identified website is a good start. However, online visibility is no longer limited to the approaches of Web 1.0. The dissemination of information as a marketing strategy includes the capacity to achieve a good position in the lists of results generated by the various search engines, as well as a presence in Web 2.0 communities and services. For its part, the "Authority" factor refers to the governmental character of the institution to which a given website pertains, along with its capacity to receive external links and communicate with its users (see Table 3).

Online presence of the World Heritage Site: This is an essential condition to ensure the searchability and findability of the website using search engines and directories. The World Heritage Site, as an independent entity, is identified and represented online either via a blog, produced by an official institution, or via its own institutional domain. The concept of the institutional domain (Aguillo, "Hacia un Concepto Documental"; Aguillo, "Measuring the Institution's Footprint") is defined as "a web page, or a set of them, hierarchically linked to a home page and identified by a URL, which forms a recognizable documentary unit that is independent of others due to its subject, authorship or institutional representation" (Arroyo Vázquez and Pareja Pérez, "Obtención de Datos"). These institutional domains have the advantage of being readily identified by search engines; however, they are not recognized by tools for analyzing links and popularity.

Representation of the World Heritage Site on social networks: For the indicator, this concept was expressed in the form of the following question: "Does the URL in question have a link to a social network?" This enabled us to prevent confusion with the multitude of other accounts on social networks that do not correspond to official organizations. Likewise, we based our assessment on whether the World Heritage Site in question had a Wikipedia page, and not the page being studied.

Communication: Opportunities for informative feedback, e.g., whether it is possible for users to contact the department responsible for the World Heritage Site in the body or institution that manages it. The two most common forms of communication with users were online forms and email, followed by online chats. 
Reputation: Considered in terms of the type of official body that is responsible for the website in question. The type of body represented by the institutional domain: e.g., foundations, trusts, associations (such as the MPPM Association-Monte Perdido World Heritage Site) and so on, where this was considered a factor that could influence the visibility. Since many of these websites were created only recently, we did not consider it necessary to assess how up to date they were.

\begin{tabular}{|c|c|c|c|c|c|c|}
\hline PRESENCE: 296.29 & $\begin{array}{l}\text { 1. URL } \\
\text { architecture of the } \\
\text { World Heritage } \\
\text { Site (Web 1.0) }\end{array}$ & $\begin{array}{l}\text { 2. Presence of the } \\
\text { World Heritage } \\
\text { Site on social } \\
\text { networks }\end{array}$ & $\begin{array}{l}3 . \\
\text { Communication }\end{array}$ & 4. Reputation & Total & Weight \\
\hline $\begin{array}{l}\text { 1. URL architecture of the } \\
\text { World Heritage Site (Web 1.0) }\end{array}$ & & 2 & 2 & 1 & 5 & 105.82 \\
\hline $\begin{array}{l}\text { 2. Presence of the World } \\
\text { Heritage Site on social networks }\end{array}$ & 0.5 & & 2 & 1 & 3.5 & 74.07 \\
\hline 3. Communication & 0.5 & 0.5 & & 0.5 & 1.5 & 31.75 \\
\hline 4. Reputation & 1 & 1 & 2 & & 4 & 84.66 \\
\hline Total & 2 & 3.5 & 6 & 2.5 & 14 & 296.30 \\
\hline
\end{tabular}

Table 3: Weighting of the Categories in the "Presence" Criterion

As mentioned above, alongside the questionnaire we also conducted a study of popularity, understood as the number of links received by other websites of an institutional nature. This also increases visibility in search engines and positioning in popularity rankings.

\subsubsection{Criterion: Audience}

The audience is the "meta-reader," the person for whom the author is writing (Pearson, Terms in Context, 61). In this instance, although the subject matter itself is highly specific, the categories of user vary greatly depending on needs and interests, and it is necessary to cater to all potential demands. We can measure this by identifying the presence of information that is relevant to the user's needs depending on the type of content.

Type of content: As we are studying a specific subject area, it was not necessary to subdivide it further. Our analysis is audience-oriented and aims to answer the question of whether there is useful information for different types of user, and therefore for different areas of interest, e.g., practical information (opening hours, how to get there, entry costs, etc.), historical and biological information, and tourist information (accommodation, restaurants, etc.).

\subsubsection{Criterion: Browsability and Accessibility}

When users access the website of a World Heritage Site, they are normally looking for specific information. Browsability refers to "the presentation and arrangement of the information on the 
screen that can influence the ease with which that information is assimilated" (Cook, "Functional Movement," 72). In this category we have treated browsability and accessibility as a single concept, given that the aim of both is for information to be located, acquired and understood by the user. This, in turn, enables us to assess various factors (see Table 4):

\section{Design of Materials:}

o Sitemap: To give every user a clear, quick overview of the different sections of the website, so that $\mathrm{s} / \mathrm{he}$ can locate the information s/he is looking for.

o Services and products offered: The design of the website must allow for a convenient, simple overview of the information it contains. The content may be static or it may provide access to products of potential interest.

\section{o Maps, Audiovisual Materials, etc.}

Accessibility: We have emphasized the relevance of the design factor, as it forms the basis of our hypothesis that the presence and visibility of information on the institutional website of the World Heritage Site is increased when the institutional domain in question places strong emphasis on accessibility. For example, the use of accessible formats instead of the Flash format.

o We must consider technical accessibility into account, given the obligations imposed upon public administrations in Spain (Gómez del Pulgar Rodríguez de Segovia, "Nueva Propuesta"). The Web Accessibility Initiative (W3C, "Standards") establishes three levels of priority, which are assessed automatically using the online tools $\mathrm{TAW}^{13}$ and HERA. ${ }^{14}$

o We must also consider linguistic accessibility, in terms of the possibility of accessing the information on the website in more than one language. Here, the use of Google Translate is given a low value (0.5), as it does not consider questions of localization.

\begin{tabular}{|c|c|c|c|c|c|}
\hline $\begin{array}{l}\text { BROWSABILITY AND } \\
\text { ACCESIBILITY: 259.26 } \\
\end{array}$ & $\begin{array}{l}\text { 1. Design of } \\
\text { materials }\end{array}$ & $\begin{array}{l}\text { 2. Technical } \\
\text { accessibility }\end{array}$ & $\begin{array}{l}\text { 3. Linguistic } \\
\text { accessibility }\end{array}$ & Total & Weight \\
\hline 1. Design of materials & & 1 & 1 & 2 & 86.42 \\
\hline 2. Technical accessibility & 1 & & 1 & 2 & 86.42 \\
\hline 3. Linguistic accessibility & 1 & 1 & & 2 & 86.42 \\
\hline Total & 2 & 2 & 2 & 6 & 259.26 \\
\hline
\end{tabular}

Table 4: Weighting of the Browsability and Accesibility Criterion

\footnotetext{
${ }^{13}$ See http://www.tawdis.net.

${ }^{14}$ See http://www.sidar.org/hera/index.php.es and http://www.sidar.org/ex_hera/index.php.es.
} 
We have yet to determine the questions (or items) that will allow us to apply the empirical method after performing an audit of each institutional domain. The only exception is in the "Audience" category, as there is only one item to assess. Tables 5, 6, and 7 correspond to the new subdivision of the "Presence and Authority" criterion. This category contains a great amount of information to be compiled, which causes a loss of specific weight for each item.

\begin{tabular}{|l|r|r|r|r|r|}
\hline $\begin{array}{l}\text { A. URL architecture of the World } \\
\text { Heritage Site (Web 1.0): 105.82 }\end{array}$ & $\mathbf{1}$ & $\mathbf{2}$ & $\mathbf{3}$ & Total & Weight \\
\hline 1. Is it an institutional domain? & & 0.5 & 1 & 1.5 & 22.68 \\
\hline 2. Does it have its own website? & 2 & & 2 & 4 & 60.47 \\
\hline 3. Does it have a blog? & 1 & 0.5 & & 1.5 & 22.68 \\
\hline Total & 3 & 1 & 3 & 7 & 105.82 \\
\hline
\end{tabular}

Table 5: Weighting of the "URL architecture (Web 1.0)" Category

\begin{tabular}{|l|r|r|r|r|r|r|r|}
\hline $\begin{array}{l}\text { B. Presence of the World Heritage Site on social } \\
\text { networks: 74.07 }\end{array}$ & $\mathbf{1}$ & $\mathbf{2}$ & $\mathbf{3}$ & $\mathbf{4}$ & $\mathbf{5}$ & Total & Weight \\
\hline 1. Does it have a link to Twitter? & & 1 & 1 & 1 & 0.5 & 3.5 & 11.78 \\
\hline 2. Does it have a presence on Facebook? & 1 & & 1 & 1 & 0.5 & 3.5 & 11.78 \\
\hline 3. Does it have a presence on YouTube? & 1 & 1 & & 1 & 0.5 & 3.5 & 11.78 \\
\hline 4. Does it have a presence on other social networks? & 1 & 1 & 1 & & 0.5 & 3.5 & 11.78 \\
\hline 5. Does it have a Wikipedia entry? & 2 & 2 & 2 & 2 & & 8 & 26.94 \\
\hline Total & 5 & 5 & 5 & 5 & 2 & 22 & 74.07 \\
\hline
\end{tabular}

Table 6: Weighting of the "Presence on Social Networks" Category

\begin{tabular}{|l|r|r|r|r|}
\hline D. Reputation: 84.66 & 1 & 2 & Total & Weight \\
\hline $\begin{array}{l}\text { 1. What type of body owns the website? Is it an official, government- } \\
\text { run institution? }\end{array}$ & & & & \\
\hline 2. Does it have external links? & 1 & & 1 & 42.33 \\
\hline Total & 1 & 1 & 1 & 42.33 \\
\hline
\end{tabular}

Table 7: Weighting of the "Reputation" Category

Additionally, the "Browsability and Accessibility" criterion is also of significant interest, due to its inclusion of some of these elements (see Tables 8 and 9). 


\begin{tabular}{|c|c|c|c|c|}
\hline A. Design of materials: $\mathbf{8 6 . 4 2}$ & 1 & 2 & Total & Weight \\
\hline 1. Is there a sitemap? & & 1 & 1 & 43.21 \\
\hline 2. Does the website offer maps and/or audiovisual materials? & 1 & & 1 & 43.21 \\
\hline Total & 1 & 1 & 2 & 86.42 \\
\hline
\end{tabular}

Table 8: Weighting of the "Design of Materials" Category

\begin{tabular}{|l|r|r|r|r|}
\hline C. Linguistic accessibility: 86.42 & $\mathbf{1}$ & $\mathbf{2}$ & Total & Weight \\
\hline $\begin{array}{l}\text { Main language of the website } \\
\text { (Spanish) }\end{array}$ & & 1 & 1 & 43.21 \\
\hline 2. Pages in other languages & 1 & & 1 & 43.21 \\
\hline Total & 1 & 1 & 2 & 86.42 \\
\hline
\end{tabular}

\section{Table 9: Weighting of the "Linguistic Accessibility" Category}

Finally, this allowed us to produce the assessment form, which we applied to the institutional domains of the bodies responsible for the World Heritage Site in question (García-Santiago and Olvera-Lobo, "Mexican World"). Table 10 shows the proposed indicators for this study, and the column titled "value" shows the importance of each element according to its weight and category. For the most part they are dichotomous variables, with the exception of indicators 11, $15,16,18$, and 19. Nowadays W3C standards, which are represented by WAI logotypes, is the most usual but not the only one. To avoid any kind of exclusion we have integrated all forms of technical mechanisms oriented towards accessibility into one concept. That's why we have included in a single item the concept of technical accessibility (Jiménez Penett, et al., "Accesibilidad de Sitios Web").

\begin{tabular}{|l|r|l|}
\hline \multicolumn{2}{|c|}{ Proposed Assessment Questionnaire } & \multicolumn{2}{|l|}{} \\
\hline INDICATORS & VALUE & SCORE \\
\hline IDENTIFICATION & 148.15 & \\
\hline A. Elements that identify the World Heritage Site online & 148.15 & \\
\hline & & \\
\hline 1. Is the URL sufficiently indicative of the institutional domain in question? & 29.63 & $0-1$ \\
\hline 2. Website title and keywords & 118.52 & $0-1$ \\
\hline PRESENCE & 296.30 & \\
\hline A. Visibility of the World Heritage Site (Web 1.0) & 105.82 & \\
\hline 3. Is it an institutional domain? & 22.68 & $0-1$ \\
\hline
\end{tabular}




\begin{tabular}{|c|c|c|}
\hline 4. Does it have its own website? & 60.47 & $0-1$ \\
\hline 5. Does it have a blog? & 22.68 & $0-1$ \\
\hline B. Representation of the World Heritage Site on social networks & $\mathbf{7 4 . 0 7}$ & \\
\hline 6. Does it have a link to Twitter? & 11.78 & $0-1$ \\
\hline 7. Does it have a presence on Facebook? & 11.78 & $0-1$ \\
\hline 8. Does it have a presence on YouTube? & 11.78 & $0-1$ \\
\hline 9. Does it have a presence on other social networks? & 11.78 & $0-1$ \\
\hline 10. Does it have a Wikipedia entry? & 26.94 & $0-1$ \\
\hline C. Communication & 31.75 & \\
\hline 11. Can the user contact the body responsible for the World Heritage Site? & 31.75 & $0-2$ \\
\hline D. Reputation and popularity & 84.66 & \\
\hline $\begin{array}{l}\text { 12. What type of body owns the website? Is it an official, government-run } \\
\text { institution? }\end{array}$ & 42.33 & $0-1$ \\
\hline 13. Does it have external links? & 42.33 & $0-1$ \\
\hline \multicolumn{3}{|l|}{ AUDIENCE } \\
\hline A. Audience & 296.30 & \\
\hline $\begin{array}{l}\text { 19. What type of information/data (historical-biographical, natural-geological, flora } \\
\text { and fauna, tourist-oriented, practical/functional) does it provide? }\end{array}$ & 296.30 & $0-2$ \\
\hline BROWSABILITY AND ACCESSIBILITY & 259.26 & \\
\hline A. Design of materials & 86.42 & \\
\hline 14. Is there a sitemap? & 43.21 & $0-1$ \\
\hline 15. Does it offer maps and/or audiovisual materials? & 43.21 & $0-2$ \\
\hline B. Technical accessibility & 86.42 & \\
\hline $\begin{array}{l}\text { 16. Does it have any type of mechanism to aid technical accessibility, or display } \\
\text { WAI-AA (or even WAI-AAA) logos? }\end{array}$ & 86.42 & $0-2$ \\
\hline C. Linguistic accessibility & 86.42 & \\
\hline 17. Main language of the website (Spanish) & 43.21 & $0-1$ \\
\hline 18. Pages in other languages & 43.21 & $0-2$ \\
\hline OVERALL SCORE & 1000.00 & \\
\hline
\end{tabular}

\section{Table 10: The IPABA Model: Indicator Values}

A value of 0.5 was given for multilingual pages that use Google Translate, while a value of 1 was given for having pages in more than one language and a value of 2 for having pages in more than two languages. The overall score for each website was calculated by adding each of the values obtained for each item. The highest score that could be achieved was 1000 .

\subsection{Calculating the IPABA Indicator}

After we had gathered all the data and made all the calculations using statistical software, we produced an overall ranking and a ranking by country. 


\section{Results}

\subsection{Elements to Potentially Facilitate Visibility Most Commonly Used on the Websites}

To determine whether the visibility and dissemination of the website improved through the identification of its design-and-content-related aspects, we performed a heuristic evaluation of the quality of the websites using the IPABA protocol. The indicator was calculated by adding the scores obtained for each item. The scores ranged from 247 to 854, with 1000 being the theoretical maximum achievable. Some $50 \%$ of results fell within the range of 535 and 724 points (the 25th and 75th percentiles). The average score was 634.9 points; however, $50 \%$ of the websites achieved a score of 678 points or greater. As we can see in Table 11, catering to a diverse audience and having external links were two of the most important factors for the websites in our sample, followed by identification, positioning, communication, and authority.

\begin{tabular}{|c|c|}
\hline INDICATORS & Results (\%) \\
\hline \multicolumn{2}{|l|}{ IDENTIFICATION } \\
\hline \multicolumn{2}{|l|}{ A. Elements that identify the World Heritage Site online } \\
\hline 1. Is the URL sufficiently indicative of the institutional domain in question? & $83 \%$ \\
\hline 2. Website title and keywords & $82 \%$ \\
\hline \multicolumn{2}{|l|}{ PRESENCE } \\
\hline \multicolumn{2}{|l|}{ A. Visibility of the World Heritage Site (Web 1.0) } \\
\hline 3. Is it an institutional domain? & $55 \%$ \\
\hline 4. Does it have its own website? & $46 \%$ \\
\hline 5. Does it have a blog? & $15 \%$ \\
\hline \multicolumn{2}{|l|}{ B. Representation of the World Heritage Site on social networks } \\
\hline 6. Does it have a link to Twitter? & $51 \%$ \\
\hline 7. Does it have a presence on Facebook? & $58 \%$ \\
\hline 8. Does it have a presence on YouTube? & $39 \%$ \\
\hline 9. Does it have a presence on other social networks? & $32 \%$ \\
\hline 10. Does it have a Wikipedia entry? & $67 \%$ \\
\hline \multicolumn{2}{|l|}{ C. Communication } \\
\hline 11. Can the user contact the body responsible for the World Heritage Site? & $80 \%$ \\
\hline \multicolumn{2}{|l|}{ D. Reputation and popularity } \\
\hline \multicolumn{2}{|l|}{$\begin{array}{l}\text { 12. What type of body owns the website? Is it an official, government-run } \\
\text { institution? }\end{array}$} \\
\hline 13. Does it have external links? & $98 \%$ \\
\hline \multicolumn{2}{|l|}{ AUDIENCE } \\
\hline A. Audience & \\
\hline
\end{tabular}




\begin{tabular}{|c|c|}
\hline $\begin{array}{l}\text { 19. What type of information/data (historical-biographical, natural-geological, } \\
\text { flora and fauna, tourist-oriented, practical/functional) does it provide? }\end{array}$ & $97 \%$ \\
\hline \multicolumn{2}{|l|}{ BROWSABILITY AND ACCESSIBILITY } \\
\hline \multicolumn{2}{|l|}{ A. Design of materials } \\
\hline 14. Is there a sitemap? & $41 \%$ \\
\hline 15. Does it offer maps and/or audiovisual materials? & $10 \%$ \\
\hline \multicolumn{2}{|l|}{ B. Technical accessibility } \\
\hline $\begin{array}{l}\text { 16. Does it have any type of mechanism to aid technical accessibility, or display } \\
\text { WAI-AA (or even WAI-AAA) logos? }\end{array}$ & $25 \%$ \\
\hline C. Linguistic accessibility & $7 \%$ \\
\hline 17. Main language of the website (Spanish) & $96 \%$ \\
\hline 18. Pages in other languages & $53 \%$ \\
\hline
\end{tabular}

\section{Table 11: Prevalence of Each Factor in the Sample}

To what extent are Web 2.0 applications present on the official websites for World Heritage Sites?

In overall terms (see Table 12), the social network most frequently used to give World Heritage Sites a Web 2.0 presence was Facebook (46\%), followed by Twitter (39\%) and YouTube (37\%). For Facebook and Twitter, a significant number $(11 \%)$ of World Heritage Sites did not have their own accounts; rather, the corresponding information was disseminated through the various messages posted by the body responsible for the World Heritage Sites in question and which owned the social media accounts.

\begin{tabular}{|c|c|c|c|c|c|}
\hline & Blog & Twitter & Facebook & YouTube & Other networks \\
\hline YES (\%) & $15 \%$ & $39 \%$ & $46 \%$ & $37 \%$ & $26 \%$ \\
\hline BODY (\%) & $0 \%$ & $11 \%$ & $11 \%$ & $3 \%$ & $5 \%$ \\
\hline NO (\%) & $85 \%$ & $49 \%$ & $42 \%$ & $61 \%$ & $68 \%$ \\
\hline
\end{tabular}

\section{Table 12: Accounts on Social Networks (\%)}

We also conducted a more detailed analysis by country to determine whether nationality influenced the social media format chosen and whether the account in question pertains to the World Heritage Site itself or the institution responsible for it. Table 13 shows that YouTube was, by a significant margin, the most popular choice in Mexico (53\%). Moreover, Mexico's favoring of audiovisual dissemination is underlined through its preference for other networks such as Instagram and Pinterest, and the frequent inclusion of maps and audiovisual materials on its websites. The use of Facebook and blogs, however, was very similar in both countries, while Table 14 shows that Twitter was the most commonly used social network in Spain. 
It should also be noted that, in Mexico, the social network accounts tended to belong to the institutions (30\%), to the detriment of the visibility of the individual World Heritage Sites they are responsible for.

\begin{tabular}{|c|c|c|c|c|c|}
\hline SPAIN & Blog & Twitter & Facebook & YouTube & Other networks \\
\hline YES (\%) & $11 \%$ & $32 \%$ & $32 \%$ & $17 \%$ & $12 \%$ \\
\hline BODY (\%) & $0 \%$ & $0 \%$ & $0 \%$ & $0 \%$ & $0 \%$ \\
\hline NO (\%) & $83 \%$ & $49 \%$ & $48 \%$ & $73 \%$ & $80 \%$ \\
\hline
\end{tabular}

Table 13: Accounts on Social Networks (\%), Spain

\begin{tabular}{|c|c|c|c|c|c|}
\hline MEXICO & Blog & Twitter & Facebook & YouTube & Other networks \\
\hline YES (\%) & $12 \%$ & $21 \%$ & $37 \%$ & $\mathbf{5 3 \%}$ & $37 \%$ \\
\hline BODY (\%) & $0 \%$ & $30 \%$ & $30 \%$ & $7 \%$ & $14 \%$ \\
\hline NO (\%) & $88 \%$ & $49 \%$ & $33 \%$ & $40 \%$ & $49 \%$ \\
\hline
\end{tabular}

Table 14: Accounts on Social Networks (\%), Mexico

\subsection{Has the IPABA Indicator Identified Differences between Each Country?}

The Kolmogorov-Smirnov normality test showed that the set of scores obtained for each institutional domain did not follow a normal distribution. After performing a Mann-Whitney U test $(\mathrm{p}<.05)$ (a nonparametric test of the null hypothesis) and Levene's test (to assess the equality of variances for a variable calculated for two or more groups) we confirmed that there was no equality of means or variances in the distribution of scores by country. The interquartile range in the group of Mexican samples is lower, while $50 \%$ of the scores are in excess of 634 points. For the Spanish samples, $75 \%$ obtained a score in excess of 600 points (up to 698 points), although there were five atypical values and one extreme value.

After analyzing the overall scores, we found that the Spanish websites made greater use of mechanisms of dissemination and accessibility, according to the IPABA questionnaire, and therefore achieved a higher mean score $(M=672.7 \mathrm{SD}=115.6)$ than their Mexican equivalents $(\mathrm{M}=572.5, \mathrm{SD}=149.7)$. We can therefore assert that there are differences between the countries in the way that information about their World Heritage Sites at the institutional level is disseminated online (see Table 15). 


\begin{tabular}{|l|l|l|l|l|l|l|l|l|}
\hline & $\mathbf{N}$ & Mean & $\begin{array}{l}\text { Standard } \\
\text { deviation }\end{array}$ & $\begin{array}{l}\text { Standard } \\
\text { error }\end{array}$ & $\begin{array}{l}\text { Confidence interval for } \\
\text { the mean at 95\% }\end{array}$ & Minimum & Maximum \\
\hline & & & & & $\begin{array}{l}\text { Lower } \\
\text { limit }\end{array}$ & $\begin{array}{l}\text { Upper } \\
\text { limit }\end{array}$ & & \\
\hline SPAIN & 71 & 672.7042 & 115.60516 & 13.71981 & 645.3409 & 700.0675 & 284.00 & 854.00 \\
\hline MEXICO & 43 & 572.5581 & 149.77480 & 22.84044 & 526.4643 & 618.6520 & 247.00 & 765.00 \\
\hline Total & 114 & 634.9298 & 137.81716 & 12.90776 & 609.3572 & 660.5024 & 247.00 & 854.00 \\
\hline
\end{tabular}

Table 15: Descriptive Statistics of IPABA Index by Country

\section{Conclusions}

Our IPABA index represents the first step in identifying quality-related elements that influence the popularity of institutional websites for World Heritage Sites. Social networks are still not used as a matter of routine to disseminate knowledge regarding cultural heritage. We observed differences in social network preferences between the two countries studied. While Mexico clearly favored the audiovisual medium of YouTube, Spain preferred to use Facebook and Twitter.

In the case of Mexico, its institutions should be aware that a dedicated account for a particular cultural and/or natural heritage site would be a powerful tool, and one that is not incompatible with the institution's own account. Moreover, the coexistence of these two accounts would not be to the detriment of either; rather, it would foster greater focus on the part of users and allow for better determination of the information to be disseminated based on the area of interest.

Many questions have been raised, which require further investigation to find the answers. One is the difference between countries in terms of visibility and accessibility, and how these factors can have a positive impact in terms of increasing popularity. Another area for further study is identifying the positive and negative impacts of social networks with regard to the dissemination and accessibility of the official websites for World Heritage Sites.

Moreover, we believe that the potential visibility of a website can be assessed to assist web designers and administrators. It would even be possible to automatically identify the existence of elements that must be taken into account to ensure optimum finding of information on official websites.

In the future, our aim is to conduct an analysis of entire websites to study the relationship between popularity and web traffic, in accordance with the categories of visibility and accessibility. To do this, we will use a greater number of search engines and will compare the results. 


\section{References}

Aaltojärvi, Inari, Ilkka Arminen, Otto Auranen, and Hanna-Mari Pasanen. "Scientific Productivity, Web Visibility and Citation Patterns in Sixteen Nordic Sociology Departments." Acta Sociologica 51.1 (March 2008): 5-22.

Abu-Serriah, Muammar, L. Wong, Daljit Dhariwal, and R. J. Banks. "Assessment of Online Visibility of the British Association of Oral and Maxillofacial Surgeons (BAOMS): A Strategic Study.” British Journal of Oral and Maxillofacial Surgery 52.2 (2014): 154-57.

Aguillo, Isidro. "Measuring the Institution's Footprint in the Web." Library Hi Tech 27.4 (2009): 540-56.

Aguillo, Isidro. "Hacia un Concepto Documental de Sede Web." El Profesional de la Información. 7.1-2 (1998): 45-6.

Arroyo Vázquez, Natalia, and Víctor Manuel Pareja Pérez. "Metodología para la Obtención de Datos con Fines Cibermétricos." Proceedings of the III Taller de Indicadores Bibliométricos, March 2003. Madrid. At http://hdl.handle.net/10261/4298 (accessed October 1, 2017).

Calle Vaquero, Manuel de la, and Agustín Ruiz Lanuza. "Ciudades Patrimonio de la Humanidad y Turismo: Un Ámbito de Reflexión Compartido.” XV Encuentro de Latinoamericanistas Españoles, November 2012. Madrid: Trama Editorial/CEEIB, 2013, pp. 870-86.

Caro, Angélica, Coral Calero, and María Ángeles Moraga. “Are Web Visibility and Data Quality Related Concepts?” Internet Computing, IEEE, 15.2 (2011): 43-49.

Ciolek, T. Matthew. "The Six Quests for the Electronic Grail: Current Approaches to Information Quality in WWW Resources." Revue Informatique et Statistique dans les Sciences Humaines (RISSH) 32.1-4 (1996): 176. At http://www.ciolek.com/PAPERS/six-quests 1996.html (accessed January 25, 2017).

Codina, Luis. Evaluación de Calidad en Sitios Web: Metodología de Proyectos de Análisis Sectoriales y de Realización de Auditorías. Barcelona: Universidad Pompeu Fabra, 2006. At http://eprints.rclis.org/8854/1/procedimientos2006.pdf (accessed October 30, 2017).

Cook, Gray, Lee Burton, K. Fields, Kyle Kiesel, and J. Van Allen. "Functional Movement Screening: Upper and Lower Quarter Applications." MidAmerica Athletic Trainer's Annual Symposium. Sioux Falls, South Dakota, 1999.

Drèze, Xavier, and Fred Zufryden. "Measurement of Online Visibility and Its Impact on Internet Traffic.” Journal of Interactive Marketing 18.1 (2004): 20-37.

Espadas, Javier, Coral Calero, and Mario Piattini. "Web Site Visibility Evaluation.” Journal of the American Society for Information Science and Technology 59.11 (2008): 1727-42. 
García-Santiago, Lola, and María-Dolores Olvera-Lobo. "Mexican World Heritage Information on the Web: Institutional Presence and Visibility." Information Development (February 2017). [Access this article through the DOI: 10.1177/0266666917692388.]

Gómez Cobos, Emilio, and Pilar Martínez-Osorio Ibarra. "Visibilidad en la Web de los Colegios Oficiales de Aparejadores, Arquitectos Técnicos e Ingenieros de Edificación de Andalucía." Revista General De Información y Documentación, 25.2 (2015): 313-39.

Gómez del Pulgar Rodríguez de Segovia, Gloria. "Nueva Propuesta de un Modelo para la Evaluación de las Páginas Web de la Administración General del Estado.” X Jornadas de Gestión de la Información, November 20-21, 2008. Madrid: SEDIC, 2008, pp. 59-73. See http://hdl.handle.net/10760/12556 (accessed November 1, 2017) .

Gordon-Murnane, Laura. "Evaluating Net Evaluators.” Searcher 7.2 (1999): 57-66.

Gori, Marco, and Ian Witten. "The Bubble of Web Visibility: Promoting Visibility as Seen Through the Unique Lens of Search Engines." Communications of the ACM 48.3 (March 2005):115-117.

Hassan Montero, Yussuf. "Factores del Diseño Web Orientado a la Satisfacción y No-frustración de Uso." Revista española de Documentación Científica 29.2 (2006): 239-57.

Ismail, Joseph. A., Theodore Labropoulos, Juline E. Mills, and Alastair Morrison. "A Snapshot in Time: The Marketing of Culture in European Union NTO Web Sites." Tourism Culture \& Communication 3.3 (March 2001): 165-79.

Jiménez Penett, Jaime, José Francisco García Gutiérrez, and Clara Bermúdez Tamayo. “Accesibilidad de Sitios Web sobre Salud para Mayores.” Revista Española de Geriatría y Gerontología 44.6 (2009): 342-48.

Jiménez Piano, Marina. "Evaluación de Sedes Web.” Revista española de documentación científica. 24.4 (2001): 405-432.

Jiménez Piano, Marina, and Virginia Ortiz-Repiso. Evaluación y Calidad de Sedes Web. Gijón: Trea, 2007.

Knight, Shirlee-ann, and Janice Burn. "Developing a Framework for Assessing Information Quality on the World Wide Web." Informing Science 8 (2005): 159-72.

Kouchay, Shouket Ahmad. "Evaluation of World Ranking, Web Visibility and Content Accessibility of Quran Web Portals.” Technology 54.1 (2014): 29-38.

Lee, Moosung, and Han Woo Park. "Exploring the Web Visibility of World-class Universities." Scientometrics 90 (2012): 201-18.

Lim, Yon Soo, and Han Woo Park. "How Do Congressional Members Appear on the Web? Tracking the Web Visibility of South Korean Politicians." Government Information Quarterly 28.4 (2011): 514-21 
Liu, Chung-Tzer, Timon C. Du, and Hsiao-Hao Tsai. "A Study of the Service Quality of General Portals." Information \& Management 46.1 (2009): 52-6.

Miranda, Francisco Javier, Sergio Rubio, and Antonio Chamorro. "An Assessment Methodology for Hotel Websites: Application to the Top 10 Cities." International Journal of Service Science, Management, Engineering, and Technology 4.3 (July 2013): 1-17.

Morville, Peter. “Ambient Findability: What We Find Changes Who We Become.” N.p.: O'Reilly Media Inc., 2005.

Palau Sampio, Dolors, and Josep Lluís Gómez i Mompart. "Calidad y Credibilidad, un Binomio Inexorable para el Futuro de los Medios.” Periodística: revista acadèmica 16 (2017): 11-28.

Pearson, Jennifer. Terms in Context. Amsterdam and Philadelphia: John Benjamins Publishing, 1998.

Pemberton, Steven. "The Kiss of the Spiderbot." Interactions 10.1 (January/February 2003). [Access this article through the DOI: 10.1145/604575.604594.]

Samadbeik, Mahnaz, Maryam Ahmadi, Ali Mohammadi, and Beniamin Mohseni Saravi. "Health Information on Internet: Quality, Importance, and Popularity of Persian Health Websites." Iranian Red Crescent Medical Journal 16.4 (April 2014):e12866. See https://www.ncbi.nlm.nih.gov/pmc/articles/PMC4028768 (accessed November 1, 2017).

Schmidt, Serje, Antoni Serra Cantallops, and Cristiane Pizzutti dos Santos. "The Characteristics of Hotel Websites and Their Implications for Website Effectiveness." International Journal of Hospitality Management 27.4 (2008): 504-16.

Singal, Himani, and Shruti Kohli. "Trust Necessitated through Metrics: Estimating the Trustworthiness of Websites." Procedia Computer Science 85 (2016): 133-40.

Ureña Gomez-Moreno, Jose Manuel, and Miriam Buendía. “¿Cómo Diseñar un Corpus de Calidad? Parámetros de Evaluación.” Sendebar 21 (2010): 165-80.

Vilar Barrio, José Francisco, Fermín Gómez Fraile, and Miguel Tejero Monzón. Las Siete Nuevas Herramientas para la Mejora de la Calidad. Madrid: Fundación Confemetal, 1997.

W3C. “W3C Standards.” See https://www.w3.org/standards. (accessed November, 1, 2017).

Wang, Fang, and Bixia Xu. "Who Needs To Be More Visible Online? The Value Implications of Web Visibility and Firm Heterogeneity." Information \& Management 54.4 (June 2017): 506-15.

Wang, Fang, and Liwen Vaughan. "Firm Web Visibility and Its Business Value." Internet Research 24.3 (2014): 292-312.

Weitzel, Leila, Paulo Quaresma, and José Palazzo M. de Oliveira. "Evaluating Quality of Health Information Sources.” Advanced Information Networking and Applications (AINA), IEEE 26th International Conference (March 2012): 655-62. 
Wierenga, Klaas. "Desire: Development of a European Service for Information on Research and Education." Ariadne 5 (1996). See http://www.ariadne.ac.uk/issue5/desire (accessed November 1, 2017).

*Corresponding Author: Lola García-Santiago, Associate Professor, University of Granada, Granada, Spain. Email: mdolo@ugr.es 


\section{Bionotes}

\section{María-Dolores Olvera-Lobo}

María-Dolores Olvera-Lobo is a full professor at the University of Granada. Her areas of research are: information retrieval, advanced systems in information retrieval, specialized documentation, and Web 2.0. She also studies translation training and information resources for translators. Contact her at: SCImago Research Group, Associated Unit of the Spanish Higher Council for Scientific Research (CSIC), Madrid, Spain; University of Granada, Department of Information and Communication, Spain. Colegio Máximo, Campus de Cartuja s/n 18071 (Granada) España. Email: molvera@ugr.es.

\section{Lola García-Santiago (professional name)}

María Dolores García Santiago is an associate professor at the University of Granada. Her areas of research are: information visualization, Webmetrics, Altmetrics, Grey literature, Web 2.0, specialized information sources, and patent analysis. Contact her at: SCImago Research Group, Associated Unit of the Spanish Higher Council for Scientific Research (CSIC), Madrid, Spain; University of Granada, Department of Information and Communication, Spain. Colegio Máximo, Campus de Cartuja s/n 18071 (Granada) España. Email: mdolo@ugr.es. 